\title{
FROM DE CLÉRAMBAULT'S THEORY OF MENTAL AUTOMATISM TO LACAN'S THEORY OF THE PSYCHOTIC STRUCTURE
}

\author{
Stijn Vanheule, Ghent, Belgium
}

\section{Lacan and His Only Master}

In 1966, as he published his Écrits, Lacan added several new short pieces to his collection of highly influential psychoanalytic writings. One of the new short papers was 'On My Antecedents' (Lacan, 1966). In this remarkable text Lacan reflected on diverse authorities that had been guiding him in the development of his work, including Melanie Klein and Salvador Dalí. Others, like Alexandre Kojève and Henri Wallon - who certainly had an important impact concerning the themes Lacan refers to - were not mentioned (Roudinesco, 1993), and Claude Lévi-Strauss - who opened the path towards his structural approach to psychoanalysis - is only briefly mentioned in a footnote. The two most prominent influences that he points to are Sigmund Freud and Gaëtan Gatian de Clérambault. The reference to Freud is not surprising. After all, in the early 1950s Lacan organized his public Seminar in terms of a 'retour à Freud.' The reference to de Clérambault is more surprising, not so much because he had not mentioned him before (see e.g. Lacan, 1947, 1993), but because he gives de Clérambault a prominent place with regard to his doctoral thesis (Lacan, 1975[1932]) and

STIJN VANHEULE is Professor of Psychoanalysis and Chair of the Department of Psychoanalysis and Clinical Consulting at Ghent University (Belgium), and a psychoanalyst in private practice (member of the New Lacanian School for Psychoanalysis and World Association of Psychoanalysis). He is the author of The Subject of Psychosis: A Lacanian Perspective (Palgrave Macmillan, 2011) and Psychiatric Diagnosis Revisited: From DSM-5 to Clinical Case Formulation (Palgrave Macmillan, 2017), and of multiple papers on Lacanian and Freudian psychoanalysis, psychoanalytic research into psychopathology, and clinical psychodiagnostics. Address for correspondence: Ghent University - Department of Psychoanalysis and Clinical Consulting, H. Dunantlaan 2, B-9000 Ghent, Belgium. [Stijn.Vanheule@UGent.be]

Psychoanalysis and History 20.2 (2018): 205-228

DOI: 10.3366/pah.2018.0259

(C) Edinburgh University Press

www.euppublishing.com/pah 
makes a clear link between de Clérambault's concept of 'mental automatism' and his own structural clinical approach:

As a physician and a psychiatrist, I had introduced, under the heading of 'paranoiac knowledge,' several end results of the method of clinical exhaustion that my doctoral thesis in medicine exemplified [...] It stems from the work of Gatian de Clérambault, my only master in psychiatry. His notion of 'mental automatism,' with its metaphorical, mechanistic ideology, which is assuredly open to criticism, seems to me, in its attempt to come to grips with the [patient's] subjective text, closer to what can be constructed on the basis of a structural analysis than any other clinical approach in French psychiatry. (Lacan, 1966, p. 65)

In this quote, two things stand out in particular. On the one hand, Lacan makes a clear link between his own concept of 'paranoiac knowledge' and de Clérambault's concept of 'mental automatism,' and on the other hand, he closely connects the latter with his structural approach to psychoanalysis.

Indeed, as he indicates, in his doctoral thesis Lacan (1975[1932]) elaborated a novel approach to psychosis, which postulated a dual imaginary relation between a patient and his world at the basis of paranoia. This dual imaginary relation is rooted in an identificatory process in which the ego is captured by ideal images: Images from without invade the patient's mind, thus installing an experience of intrusion that gives rise to unshakeable convictions (Vanheule, 2011). Lacan (1975[1932], p. 337) first qualifies these convictions as 'delusional knowledge' - connaissance délirante - but later refers to them with the term 'paranoid knowledge' (e.g. Lacan, 1947, 1949). In 'On My Antecedents' Lacan justifiably linked his concept of 'paranoid knowledge' to de Clérambault's work on 'mental automatism.' After all, in both cases a psychological experience of intrusion is situated at the basis of psychosis. Yet, in the dissertation itself, references to de Clérambault are scarce, and no link at all is made between mental automatism and delusional knowledge (Maleval, 2001). It is therefore relevant to clarify why Lacan at first neglected to note the obvious connection between these concepts.

Second, in the above quote from 'On My Antecedents' Lacan suggests a close connection between his own structural approach to psychoanalysis and de Clérambault's theory of mental automatism. This is quite a statement, given the fact that de Clérambault's approach is grounded in biological and mechanical determinism, while in his structural work from the 1950s Lacan's focus is on the unconscious and on language. Therefore, the proposed link between mental automatism and Lacan's structural approach needs to be studied in detail, focusing on how their viewpoints converge and diverge. Early on in this work Lacan (1988 [1931]) used the concept of structure in relation to psychosis. At that time he referred to specific dynamics in subcategories of psychosis, which is quite in line with de Clérambault's work (Roudinesco, 1994). Yet, from the 1950s on, when Lacan was inspired by structuralist thinking, 'structure' obtained a different meaning, and now concerned the language-based functioning of the unconscious, 
giving a new twist to his use of the mental automatism concept (Haustgen \& Gumpper, 2012).

In this article I will first discuss de Clérambault's work, focusing on his concept of mental automatism. Subsequently I review the roots of the divergences between both authors, and finally I examine how mental automatism might be situated in Lacan's structural account of psychosis. As Lacan himself did not elaborate this link, I provide an interpretation as to how mental automatism fits within the Lacanian model.

\section{On de Clérambault}

Gaëtan Gatian de Clérambault (1872-1934) was a medical doctor working in the tradition of the French alienists. From 1905 onwards he worked at the Special Infirmary for the Insane of the Paris Prefecture of Police, which he led between 1920 and 1934. This small-scale service consisted of 18 cells, where people deemed potentially insane were locked up following police arrest in order that they could undergo psychiatric examination (Rubens, 1998). Detainees stayed only for brief periods and were screened for mental illness. On average, 2,500-3,000 persons per year underwent psychiatric examination in this service (Rubens, 1998). De Clérambault was well-known for his thorough but rapid clinical decision-making (Michaux, 1973), which had a specific focus: 'it [the certificate that de Clérambault wrote] is not so much concerned with labeling a disease entity, but with bringing to light, in a couple of lines and with some well-chosen words, the flamboyance of the symptom' (Rubens, 1998, p. 160). It has been estimated that he wrote between 13,000 and 15,000 certificates during his career (Gumpper \& Haustgen, 2012; Hriso, 2002). Related to his diagnostic work de Clérambault also occupied a teaching role at the Special Infirmary for the Insane, mainly consisting of public clinical presentations where he interviewed and discussed selected cases from his department.

In 1928-9 Lacan completed an internship at the Special Infirmary, supervised by de Clérambault (Roudinesco, 1993; Rubens, 1998). Like several others (e.g. Ey, 1952) he praised de Clérambault's diagnostic interview skills and talent for clinical deduction (Lacan, 1947). By many, de Clérambault is remembered as a clever examiner who managed to get in touch with patients' preoccupations very quickly and very skillfully:

In the maneuver of stirring the patient to the point of withdrawing his secret the alienist [de Clérambault] speaks all languages, apes all styles, and mobilizes all registers of speech. His ability to mimic, which aims at trapping his 'client,' is really fascinating. (Rubens, 1998, p. 157)

1. Unless otherwise noted, all translations from previously untranslated French texts are my own. 
Indeed, often de Clérambault is recalled for the subtle attention he paid to discreet details in patients' stories and speech that might be indicative of a psychotic condition (Rubens, 1998). The crucial process that he focused on was mental automatism.

Yet some authors were more disparaging of his work. From the 1920s onwards André Breton was critical of de Clérambault's harsh practices (Roudinesco, 1994). As Leguil (2002, pp. 29-32) indicates, Lacan (1975[1932]), too, was critical of aspects of de Clérambault's work at the Special Infirmary, especially the interrogatory style of de Clérambault's interviewing: through his position as 'expert' he tended to coerce confessions from patients about specific symptoms, and by doing so he failed to really listen to his patients. He avoided the subjective encounter with people arriving in crisis at this service, and hid behind objectifying schemes and ideas (Gumpper \& Haustgen, 2012). Nowadays criticism continues to be made about de Clérambault's psychiatric practice. For example, at one point he wrote a mental report about the French painter Maurice Utrillo, who suffered from severe alcoholism and had traits of schizophrenia. The report contains several factual errors, and has been described as incomplete and superficial (Biéder \& Bénézech, 2016).

\section{Mental Automatism}

Starting with a short paper in 1909 , de Clérambault proceeded to author several papers on the topic of mental automatism across the duration of his career. These articles were quite influential. In 1927 the Aliénistes et Neurologistes de France devoted their 31 st conference to this concept, bearing witness to the impact of de Clérambault's work.

De Clérambault's first detailed discussion of mental automatism stems from 1920 , and this was further elaborated through several papers of that decade (de Clérambault, 1920a, 1920b, 1923, 1924a, 1924b, 1925, 1926, 1927a, 1927b). In 1925 he defined it as 'a certain clinical syndrome consisting of automatic phenomena in three registers: motor, sensory, and ideo-verbal' (de Clérambault, 1925 , p. 528), with 'automatic phenomena' referring to the surprising occurrence of strange manifestations in the intimacy of one's body and/or mind. The person having such experiences does not feel that they belong to him. On the contrary, within a certain register of functioning (motor, sensory, and ideo-verbal) parasitic elements present themselves, to which the person feels passively subjected. De Clérambault qualifies this as an experience of disappropriation and interference, indicating that ownership in relation to the events taking place internally is missing (de Clérambault, 1926, pp. 546, 549). Likewise, given the spontaneous nature and the mechanical expansion of the events, they initially have a surprising effect on the individual. Both affectively and thematically speaking the experience is quite neutral or 'non-ideational.' What comes to the fore is bewilderment and perplexity associated with ruptures in the process of ideation, resulting in a failure to make sense of what is happening 
(de Clérambault, 1925, pp. 542-3). Such bewilderment is not a result of the mental contents that a person is confronted with, but of a fundamental disruption in the formal structure of normal experience: 'Mental automatism as such does not entail hostility. At first, the constituent phenomena are neutral at the affective level and non-thematic at the ideational level' (de Clérambault, 1923, p. 490).

Indeed, de Clérambault considers mental automatism as a comprehensive nuclear process underlying many forms of madness (de Clérambault, 1920a, 1926): 'This syndrome encompasses all types of hallucinations that we already know; however, the mental automatism concept is more comprehensive than the concept of hallucination' (de Clérambault, 1925, p. 528). While including hallucinations, mental automatism refers to a general process of interference at the level of motor, sensory-affective, or ideo-verbal functioning, which can already be observed in prodromal psychotic states (de Clérambault, 1923, 1926). Non-hallucinatory mental automatism usually precedes the occurrence of hallucinations, but both might coexist (de Clérambault, 1924a).

Within the general process of interference, de Clérambault discerned both positive and negative automatic phenomena. In other words, automatism can be expressed in terms of novel elements being added to one's functioning (positive mental automatism), or in terms of the decay of elements that habitually contribute to functions (negative mental automatism). The first make up phenomena of intrusion, and the Latter phenomena of inhibition (de Clérambault, 1924b, 1926). Table 1 gives an overview of specific clinical manifestations that de Clérambault presented as indicative of positive and negative automatic phenomena in motor, sensory-affective, or ideo-verbal functioning (see also Renard, 1992). ${ }^{2}$

Throughout his oeuvre, de Clérambault (e.g. 1924b, 1926) frequently distinguished minor automatism (petit automatisme) from major automatism (grand automatisme). Minor automatism refers to subtle positive and negative ideo-verbal phenomena that have not yet had a bewildering impact on a person's subjective functioning. Often they are hardly noticed; they are 'anideatic,' meaning that they have no specific content; and are affectively neutral. Major automatism means that sensory-affective and motor functioning are also involved, and that gross automatic phenomena, including ideo-verbal, disrupt the person's functioning. This renders the patient both perplexed and overwhelmed. Often minor automatism is followed by major automatism, but this is not always the case. Thought echoes frequently appear in the transition between these experiences (Lanteri-Laura \& Daumézon, 1961).

What is characteristic of de Clérambault's approach is that although he adhered closely to patient-materials and clinical observations, he did not elaborate

2. As can be deduced from the list in Table 1, the exact meaning of the mental automatism concept somewhat shifted as de Clérambault's work progressed. At first it refers to disruptions at the ideo-verbal level in particular. Later on motor and sensory phenomena are included in the concept, and in his later writings, affective disturbances are included as well. 


\section{Table 1. List of specific clinical manifestations that bear witness to mental automatism.}

\section{Positive phenomena at the level of ideo-verbal functioning}

- Automatic thought: surprising thoughts of which one is not the originator occur in the mind (de Clérambault, 1920a)*

- Thought control: the mind is influenced and directed by an external agent (de Clérambault, 1920a)

- Thought echoes: thoughts are heard in a repetitive way, as coming from without (de Clérambault, 1920a)

- Confusion and distraction due to indeterminable thoughts (de Clérambault, 1920a)

- Outstripped thought: thoughts occur in the mind before the individual qua thinker could have produced them (de Clérambault, 1923)

- Primitive pre-logical thinking: thought is preoccupied by playing with numbers, syllables, colors, rhythm in speech, repetitions, making gross analogies (de Clérambault, 1923)

- Fragmented thought (de Clérambault, 1924b)

- False recognition (de Clérambault, 1924b)

- Substitution of thought: ongoing thought processes are disturbed by imposed thoughts (de Clérambault, 1924b)

- Aprosexia: thought is too fast, there is an inability to focus attention on it (de Clérambault, 1924b)

- Estrangement: common objects and people are suddenly experienced as strange (de Clérambault, 1926)

Negative phenomena at the level of ideo-verbal functioning

- Stops and blanks in thought processes (de Clérambault, 1924b)

- Disappearance of thoughts (de Clérambault, 1924b)

- Perplexities without an object (de Clérambault, 1926)

\section{Positive phenomena at the level of motor functioning}

- Experience of being forced and directed at the level of one's actions (de Clérambault, 1920a)

- Automatic writing: writing down things beyond conscious control (de Clérambault, 1920a)

- Strange motor impulses (de Clérambault, 1924b)

Negative phenomena at the level of motor functioning

- Motor inhibitions (de Clérambault, 1924b)

\section{Positive phenomena at the level of sensory-affective functioning}

- Cenesthetic disturbance or cenestopathy: strange sensations that might be pleasurable or disagreeable, and manifest across the body or in specific areas (de Clérambault, 1920a)

- Strange sensory perceptions, like at the olfactory level (de Clérambault, 1923)

- Automatic quasi-visual perception of memories (de Clérambault, 1924b)

- Dysesthesia: abnormal sense of touch involving painful sensations, like needles or electric currents (de Clérambault, 1926)

- Sudden affective states, such as sadness, anxiety, joy, or anger, experienced as inappropriate (de Clérambault, 1924b)

- Estranging obsessional fears and impulses occupy the mind (de Clérambault, 1924b)

- Emotions without an object (de Clérambault, 1926)

Negative phenomena at the level of sensory-affective functioning

- Sudden fatigue (de Clérambault, 1924b)

*I only include one key reference for each automatic phenomenon de Clérambault describes. 
a broader descriptive diagnostic system focusing on particular symptoms of psychosis - such as hallucinations and delusions. What interested him was mental automatism qua fundamental mechanism at the basis of all kinds of insanity or psychosis. Moreover, while descriptive diagnostic approaches aim to reveal the overall clinical picture of diverse psychotic conditions, de Clérambault assumed that not all symptoms were of equal importance. Throughout his work he aimed to grasp the elementary building block that defined whether a condition was psychotic or not. Starting from his theory, patients with hallucinatory experiences, but without automatic phenomena, were not thought of as psychotic. Conversely, patients afflicted with automatic phenomena but without descriptive symptoms like hallucinations and delusions were indeed psychotic.

In elaborating his theory of mental automatism, de Clérambault formulated a descriptive framework that was theoretically unsophisticated. The main sources he relied on were works of predecessors in the field of French psychiatry. As de Clérambault (1923, 1924a) himself indicated, his concept of mental automatism strongly builds on Jules Baillarger's (1856) ideas about thought echoes and psychic hallucination, which concern the experience of imposed thoughts. Another important source for de Clérambault was Jules Séglas's (1888) work on verbal psychomotor hallucinations, which deals with the experience of imposed speech (Gumpper \& Haustgen, 2012; Lanteri-Laura, 2004; Lanteri-Laura \& Daumézon, 1961). What is unique to the clinical syndrome that de Clérambault described is that he grouped the latter with an extensive list of other intrusive phenomena that have a similar effect on the patient. In terms of subtypes of psychosis, de Clérambault linked mental automatism to different types of paranoia, hypochondria, mania, melancholia, and hallucinatory psychoses (de Clérambault, 1923, 1924a, 1925; Renard, 1992). However, he used a unified concept of psychosis (Hriso, 2002), as evident in his suggestion that similar automatic phenomena can give rise to different kinds of delusions. For example, cenesthetic sensations might just as well give rise to hypochondria as to delusions with a mystical or persecutory content (de Clérambault, 1925).

Key to his work is the assumption of a strict parallel between mental automatism, as observed clinically, and underlying neurological disruptions that cause the automatic phenomena. ${ }^{3}$ De Clérambault was a strict organicist thinker, and supposed that mental automatism was the negative reaction to infection, intoxication, or tumors. Given the fact that automatism itself obeys a mechanistic logic, and usually evolves in the same patterned way, he assumed that the origin had to be mechanical in nature too, rather than being rooted in psychological conflict, for example (de Clérambault, 1926). Psychological explanations were very implausible to him, and he simply set them aside (de Clérambault, 1927). Nevertheless, de Clérambault did not appear to be very interested in the issue of

3. In articulating these speculative causal links he clearly stuck to mental automatism as such, meaning that he did not link his causal account to the pathogeny of psychosis (Hriso, 2002). 
causation (Leguil, 2002). Indeed, the concept of 'mechanism' might even have played a purely metaphorical role (Miller, 1978).

In line with his idea that mental automatism constitutes the key mechanism of psychosis, further symptoms, like delusions, were seen as secondary reactions: 'the actual delusion is nothing but the obligatory reaction of a reasoning intellect, which is often intact, to phenomena arising from sub-consciousness.' Delusions are elaborations of automatic phenomena that overwhelm and disturb the individual: 'it is the intensity, the unexpected character, the constancy, and the strangeness of the sensation that prompts the subject [...] to incline towards exogenous explication' (de Clérambault, 1925, p. 533). Indeed, delusional interpretations are ideational responses that might, eventually, give rise to the elaboration of a 'second,' delusional personality (de Clérambault, 1927). Between the occurrence of automatic phenomena and the elaboration of a delusion, a so-called incubation period might occur, during which, in a discreet way, the initial experience of intrusion gradually invades the patient's broader mental life. What is characteristic of such an incubation period is confusion because of contradicting thoughts and experiences: 'an unexpected image arises, and provokes an irrefutable thought; then it becomes haunting, provoking several contradictory thoughts' (de Clérambault, 1923, p. 481).

\section{De Clérambault Questioned}

While de Clérambault provided clear descriptions of mental automatism, his reflections on the link between automatic phenomena and delusions left several questions open.

First, while he claimed that delusions were interpretations derived from automatic intrusions, the demarcation between both was not so clear. For example, in several clinical cases he presented fragments like the following, which he interpreted as indicative of automatism:

'They know all about my life. They spend their time watching and saying everything. They would say everything in front of my friend, that's why we didn't marry' $[\ldots]$

'They give me fears. They suggest that I yell at the killer in the street so that I will be arrested as an insane. They force me to complain. Occasionally I wanted to complain about someone, and then I didn't want it anymore, but I was forced into doing so.' (de Clérambault, 1924b, p. 519)

In contrast to the overall idea that mental automatism is affectively neutral, and athematic or 'non-ideational,' these fragments bear witness not just to intrusion, but also to manipulation by an external force, 'they,' which is not neutral, but malevolent in nature. Obviously, automatism and delusion might intermingle.

On this point Lacan's solution, explored some decades later in his Seminar on the psychoses, is interesting. Contradicting de Clérambault, he suggested that delusions should be seen not so much as ideational deductions or interpretations, but as variations on the same problem. At first sight delusions seem more 
complicated, but in the end they articulate the same elementary structure of interruption. In delineating both he suggests that the delusion starts as soon as an 'inmixing of subjects' is at stake (Lacan, 1993, p. 193): 'It's this that is constantly involved in delusion: One makes them do this' (Lacan, 1993, p. 194). For Lacan, mental automatism refers to the passive experience of subjective changes, while delusion implies that such alterations are attributed to external control, which defines the subject as a pawn or puppet in the hands of a manipulative other. Indeed, automatic phenomena make up 'a parasitic point' in the intimacy of mental life, and delusions further articulate this basic structure (Lacan, 1993, p. 19; Maleval, 2001).

In making this claim that delusions are not deduced from expressions of mental automatism, one sees evidence of the impact Salvador Dalí's work had on Lacan in the 1930s. Early on Dalí formulated the idea that automatism had an important role to play in the production of paranoid knowledge (Roudinesco, 1994; Garrabé, 2005). Already in his paper 'The Rotting Donkey,' Dalí (1930a) suggested that delusions do not emerge as a reaction against some primordial element, but autonomously constitute a mode of thinking that does not follow the rules of rationality. Paranoid thinking obeys a strict internal logic. It systematizes the confusion one is confronted with, and produces simulacra about the world that reveal another side of reality than the one ordinary thought brings to the fore. Dalí (1930a, 1930b) had articulated these ideas before encountering Lacan (Roudinesco, 1994; Garrabé, 2005) and it can reasonably be assumed that Dalí inspired Lacan in stressing the autonomous, non-deduced character of delusional thinking. ${ }^{4}$

Second, during a discussion of thought echoes at a conference in 1927, de Clérambault noted that mental automatism displayed a 'pejorative tendency': usually thought echoes do not express abstract ideas; they are characterized instead by a 'crudity of words, ideas and feelings' (de Clérambault, 1927b, p. 595). This is an important observation, which appears to contradict the initial belief that automatic phenomena are athematic and non-ideational. While it might well be true that mental automatism disrupts an individual's habitual patterns of ideation, and triggers ideas that a person had not been thinking of, certain thematic trends can be observed in what they bring to the fore. Indeed, the cases that de Clérambault presented across his career demonstrate that automatic phenomena often express vulgar, aggressive, death-related, or bluntly ironical contents. In his later papers, de Clérambault noted these contents, but given his non-psychological approach, he seemed to have been puzzled by them. On the one hand, de Clérambault pointed out that 'the psychology of the echo and its derivatives still needs to be established' (de Clérambault, 1927b, p. 590), but on the other hand, he concluded that the pejorative tendency has a neurological origin,

4. Roudinesco (1994, p. 1673) indicates that in 1932-3 Lacan was frequently in touch with Dalí. They probably first met in 1932 (Garrabé, 2005). 
suggesting that it reflected a neural tendency towards 'animality.' Overall, this explanation seems to point out the limits of his mechanical, organicist explanations, and precisely at this point Lacan's structural theory of foreclosure, which was elaborated in his third Seminar (Lacan, 1993) and in his 1959 paper 'On a Question Prior to Any Possible Treatment of Psychosis,' proves its value. As I explain below, while underscoring mental automatism qua clinical syndrome, Lacan went on to make the point that what is at stake in mental automatism is a typically psychotic position at the level of the unconscious: existential issues, like sexuality, death, and parenthood, cannot be addressed via lawful principles articulated by means of the Name-of-the-Father, and as a result, these themes return in jouissance-laden interruptions. Yet, already in his doctoral thesis Lacan clearly stated that mental automatism often expresses specific contents (Lacan, 1975[1932]): delusional themes are not secondary in nature, but already present in the early disruptions of mental life (Maleval, 2001).

Finally, it should also be noted that on several occasions de Clérambault expressed his discontent with the name given to the syndrome, possibly because it echoed theories that he wanted to distance himself from. These include Henri Claude's (1930) 'syndrome d'action extérieure,' which describes similar problems, but focuses more strongly on the ideas expressed via automatic phenomena, and Pierre Janet's (1889) theory of psychological automatism, which focuses on the non-conscious processing of sensory stimuli (Roudinesco, 1994). Therefore, in later papers he suggests better alternative names for the syndrome, including 'syndrome de passivité' - passivity syndrome (de Clérambault, 1925, p. 542; 1926, p. 574); 'syndrome S' (de Clérambault, 1927b, p. 588); 'syndrome d'écho' (de Clérambault, 1927b, p. 599); 'syndrome mécanique'; or 'syndrome de Clérambault' (de Clérambault, 1933, p. 607). ${ }^{5}$ However, in the later tradition of psychiatry, mental automatism proved to be the concept that is used most often to refer to this syndrome.

\section{Lacan and de Clérambault: A History of Love and Hate}

As will become clear in this section, the relationship between Lacan and de Clérambault was quite conflicted. Roudinesco (1993) indicates that during his psychiatric training Lacan was particularly influenced by three key figures of French psychiatry: Georges Dumas, a biologically oriented professor of psychiatry at the Sorbonne; Henri Claude, the chief medical doctor at the Sainte-Anne psychiatric clinic in Paris, who combined psychodynamic and organic lines of reasoning concerning psychopathology; and de Clérambault. In his later work, Lacan stressed that de Clérambault particularly influenced him. In his 1947 paper 'Presentation on Psychical Causality,' a critical piece on the work of Henri Ey,

5. In Anglo-Saxon psychiatric literature the name 'de Clérambault syndrome' is frequently used as a synonym of erotomania, which is another syndrome he documented in detail. 
he calls de Clérambault his 'only master in the observations of patients' (Lacan, 1947, p. 137), and, as already indicated, in 1966 his 'only master in psychiatry' (Lacan, 1966, p. 51). During his Seminar on the psychoses in the mid 1950s he stated that he was introduced to psychiatry via 'the intimacy' of de Clérambault (Lacan, 1993, p. 5), which suggests a relationship of confidence and friendship, and near the end of his life he still spoke of him as his good old master (Roudinesco, 1993, p. 487). However, from the early 1930s until de Clérambault's death in 1934 their relationship was troubled.

The first stumbling block between them was a 1931 paper by Lacan on paranoid psychoses. In this paper - 'Structures des psychoses paranoïaques' - Lacan reviewed subtypes of paranoia, focusing on frequently occurring clinical characteristics, typical courses of pathology, prognosis, cause, and medico-legal issues. Qua subtypes he distinguished between an overall paranoid constitution; delusions of interpretation; and delusions of passion. In reference to de Clérambault he further subdivided the latter by making a distinction between delusions of revendication, erotomania, and delusions of jealousy. Within the paper Lacan referred to the classic works of Kraepelin (mentioned twice), Sérieux and Capgras (mentioned four times), and to his teachers Claude (mentioned twice) and de Clérambault (mentioned six times). Indeed, de Clérambault is the most frequently mentioned authority in this paper, and in a footnote he pays tribute to him:

this image [the image of the annelid for referring to elementary psychotic phenomena] is borrowed from the verbal teaching of our master M.G. de Clérambault, to whom we owe much in terms of matter and method, such that, in order to avoid the risk of plagiarizing him, we have to pay tribute to him for all the concepts we use. (Lacan, 1988[1931], p. 10)

Yet, by qualifying passionate psychoses as a subtype of paranoia, Lacan actually joined sides with Claude, contradicting de Clérambault, who clearly distinguished and juxtaposed both types of psychosis (Maleval, 2001). Moreover, in discussing mental automatism Lacan used Claude's (1930) concept 'syndrome d'action extérieure,' which further distanced him from de Clérambault (Maleval, 2001). The paper infuriated de Clérambault, who publicly attacked Lacan, accusing him of plagiarism. Lacan was affected by this attack but did not bow to the accusation, suggesting that the true plagiarist was actually de Clérambault (Leguil, 2002; Roudinesco, 1993; Rubens, 1998). Obviously, by introducing ideas from Claude and Freud in his paper, Lacan did not strictly adhere to de Clérambault's ideas about paranoia and passionate psychoses (Maleval, 2001). De Clérambault was himself contemptuous about Henri Claude, ${ }^{6}$ and demanded strict loyalty from his followers (Roudineso, 1993), which Lacan did not offer.

6. 'Everybody in the small world of alienism knows the biting expression de Clérambault used for his colleague: "there you have a man who wants to make a name with two first names" (Rubens, 1998, p. 205). 
From 1930 on, Lacan associated more closely with Claude, who, in 1932, was the supervisor of his doctoral thesis and had overall academic prestige. $\mathrm{He}$ also involved himself with the surrealist movement that had been attacking de Clérambault violently from 1928 onwards because of inhumane practices in the Special Infirmary (Roudinesco, 1994; Rubens, 1998). Moreover, when Lacan (1988[1931]) published this paper, de Clérambault's health was deteriorating due to a cataract, which had a devastating impact on his ability to write.

In 1931 the split became a fact. In another paper, published later in 1931 on the topic of automatic writing in a case of paranoia (Lévy-Valensi et al., 1931), de Clérambault is still mentioned since he wrote a diagnostic report about the patient when she was staying at the Special Infirmary. Yet, his theory of mental automatism, which actually includes automatic writing (de Clérambault, 1920a), is not used. By contrast, a strong reference is made to the practice of automatic writing by surrealist authors such as André Breton. Breton publicly attacked de Clérambault for his outdated practices in the Special Infirmary, and de Clérambault, in his turn, denounced the surrealists, qualifying them as dangerous (Roudinesco, 1994; Rubens, 1998).

De la psychose paranoïaque dans ses rapports avec la personnalité, Lacan's (1975[1932]) doctoral thesis, bears further witness to this split. Key points of reference include Claude, Jaspers, Bleuler, and Kraepelin. Lacan explores de Clérambault's contributions to his research topic in only a few paragraphs. $\mathrm{He}$ mentions de Clérambault on paranoia and erotomania, but his work on mental automatism is referenced only in an early footnote (Lacan, 1975[1932], p. 25, n.14). This is remarkable considering Lacan discusses the notion of mental automatism across 14 pages (Lacan, 1975[1932], pp. 126-39), and in the case study of Aimée different types of interference, such as discreet mental intrusions and inhibitions, as well as impulses and perplexities are noted as the basis of her paranoia (e.g. Lacan, 1975[1932], pp. 156, 175-7, 189, 207-17). In his discussion of mental automatism, Lacan refers to a minor paper by Mignard \& Petit (1912), which does not provide a robust account of the topic.

At a more implicit level, the methodology Lacan (1975[1932]) applies when discussing the case of Aimée also suggested a rupture with de Clérambault. As he interviewed people incarcerated at the Special Infirmary de Clérambault had an objectifying attitude: starting from his personal dogma concerning mental automatism he examined whether and how automatism occurred. This usually took one interview, and personal contact with interviewees was limited (Gumpper \& Haustgen, 2012; Rubens, 1998). Thus considered, de Clérambault's approach was in tune with Jean-Pierre Falret's recommendation that in contrast with the narrative nosographic methods applied by Pinel and Esquirol, an alienist should not merely listen to people's stories but actively inquire about elements that point to delusional functioning (Sauvagnat, 1999). Falret stressed the apodictic saying that the alienist should not become 'a secretary to the insane' (see Sauvagnat, 1999). Lacan, for his part, obviously has an eye for diverse psychotic phenomena when discussing the case of Aimée, but does not act like a Clérambaultian 
detective. He dynamically situated such phenomena in terms of the challenges and issues that his patient was confronted with, which sets him in the direction of psychoanalysis (Vanheule, 2011). Later, when he returned to the subject of psychosis in his Seminar (1993, p. 206), Lacan further underscored the importance of such an attitude, saying that 'becoming a secretary to the insane' is actually not such a bad thing: an analyst should not merely inquire about specific psychotic phenomena but situate them in terms of a person's overall position with respect to the symbolic order.

As outlined in the introduction, in his doctoral thesis Lacan introduced the concept of 'delusional knowledge' - connaissance délirante - later called 'paranoid knowledge.' With this concept Lacan drew attention to paranoid patients' firm delusional understanding of events taking place which, in their experience, was not a product of their own cognition and imagination but was revealed automatically from without. This line of reasoning fitted very well with de Clérambault's (1920a, 1924b) descriptions of the kind of intrusion proper to automatic thinking and false recognition. However, Lacan denies this link and does not cite de Clérambault, though later, in 'On My Antecedents,' Lacan (1966) indeed points out that the roots of his concept are to be found there. It is possible that his conflicted relation with de Clérambault, his dependence on Claude, and his search for a psychogenic account of paranoia hindered him from making this connection explicit at the time (Roudinesco, 1994). ${ }^{7}$

In 1933, as he published his paper on the murders of the Papin sisters in the surrealists' journal Minotaure, Lacan alluded to de Clérambault's work in the Special Infirmary, but did not mention him explicitly:

each psychiatrist knows the most special atmosphere that is often evoked by some stereotype in the patient's narrative, even before delusional formulations have been made explicit. If one ever experienced this impression, it makes no wonder that one recognizes it. Indeed, triage in police services usually builds on this experience. (Lacan, 1933, p. 27)

Soon after de Clérambault's death in 1934, Lacan again referred to him as his 'master' (Leguil, 2002; Maleval, 2001). In 1935 he mentioned de Clérambault's theory of mental automatism stressing 'the beautiful works of this master' (Lacan, 1935, p. 428). Later on he even seemed to regret that he had actually joined sides with Claude (and the surrealists): 'Clérambault was my only master in the observations of patients, after the very subtle and delectable Trénel, whom I made the mistake of abandoning too soon, in order to seek a position in the consecrated spheres of professorial ignorance' (Lacan, 1947, p. 137). During his third Seminar, when he discussed psychoses by establishing a dialogue between psychoanalysis,

7. Note that in the preface to his thesis Lacan expressed gratitude to many, but not to Gaëtan Gatian de Clérambault. For example, he mentions Georges Heuyer, one of de Clérambault's collaborators and his successor at the Special Infirmary, but not 'the master' himself. Moreover, de Clérambault's name is missing when he lists the internships he completed in the preliminaries of his doctoral thesis (Lacan, 1975[1932], p. 12). 
psychiatry, and structural linguistics, Lacan (1993, pp. 5, 18-19) once again paid tribute to his master, providing a structural-psychoanalytic reading of his theory concerning mental automatism.

\section{Mental Automatism, Elementary Phenomena, and Structure}

As indicated in the introduction, in 1966 Lacan further rehabilitated de Clérambault by suggesting a close link between mental automatism and his own structural approach in psychoanalysis (Haustgen \& Gumpper, 2012). Seeing that Lacan himself did not elaborate on this point in detail, I examine below how this proposed connection can be understood. Following his structural method I develop a number of schemas that depict how the mental automatism concept fits with Lacan's structural theory of the subject.

In Seminar III, Lacan (1993) not only mentions de Clérambault and mental automatism quite frequently, but also attributes the concept of 'elementary phenomenon' (phénomène élémentaire) to him (Lacan, 1993, pp. 19, 34). This is remarkable since de Clérambault does not seem to use this term in writings, and rather refers to 'automatic phenomena' or 'automatisms' when talking about specific manifestations of mental automatism. Lacan uses the concept 'elementary phenomenon' from his 1931 paper on schizography onwards, and in his doctoral thesis he seems to attribute it to Kraepelin rather than to de Clérambault: 'Kraepelin describes two kinds of phenomena in psychoses: elementary disturbance and delusion' (Lacan, 1975[1932], p. 27). However, as Trichet (2011) indicates, the concept 'elementary phenomenon' actually stems from the work of the British-French neurologist Benjamin Ball (1880), who uses it to refer to basic manifestations of psychosis. Ball was the first medical chair of the Sainte-Anne hospital in Paris, where Lacan completed his psychiatric training under the supervision of Claude. He probably picked up the concept in that context. In Lacan's jargon, the concepts 'mental automatism' and 'elementary phenomenon' largely function as synonyms: mental automatism is the elementary phenomenon of psychosis.

As he discusses elementary phenomena in Seminar III, Lacan questions exactly what the adjective 'elementary' means. Sticking more closely to de Clérambault's writings, it could be said that Lacan was criticizing the suggestion that mental automatism makes up the 'initial nucleus' or the 'nuclear process' of psychosis (Lacan, 1993, p. 19). 'Elementary' and 'nuclear' might imply that these phenomena are essential or primordial in relation to other psychotic phenomena that are only 'secondary' in nature. This is what de Clérambault indicates when stating that delusions are interpretations grafted onto elementary phenomena. Such a line of reasoning reflects a process in time: first mental automatism comes to the fore, and subsequently delusions are formed. In Lacan's view, by contrast, 'elementary' denotes that the key element of psychosis is expressed: 'This means that here the notion of element is to be taken in no other way than as structure, differentiated structure, irreducible to anything other than itself' (Lacan, 
1993, p. 19). 'Elementary,' then, no longer refers to an initial moment, but to a 'structural' point that might be observed across diverse psychotic phenomena, which is why delusions too are 'elementary': just like automatic phenomena, delusions articulate the structural element that is most characteristic of psychosis:

elementary phenomena are no more elementary than what underlies the entire construction of a delusion [...] analogous structures can be found at the level of the composition, motivation, and thematization of a delusion and at the level of the elementary phenomenon. In other words, it's always the same structuring force, as it were, at work in a delusion, whether it's the whole or one of its parts that is under consideration. (Lacan, 1993, p. 19)

Within this line of reasoning the idea of structure is crucial. In the 1950s Lacan was heavily influenced by the structuralist turn in the human and social sciences (e.g. Milner, 2002), which generally aimed to grasp the logical organization of given phenomena by mapping the relations between their constituent elements. In Seminar III, Lacan defined structure as 'a group of elements forming a covariant set [...] A structure is always established by referring something coherent to something else, which is complementary to it' (Lacan, 1993, p. 183). Within this logic, structure implies dependency between elements. In a group consisting of the elements $\mathrm{A}, \mathrm{B}$, and $\mathrm{C}$ structural relations are established if, for example, changes in A imply changes in B, which might further be influenced by what happens at the level of C. In this case, the elements A, B, and C make up a set, meaning that between these elements decisive relations are established.

What is crucial to Lacan's understanding of structure in the 1950s is that he connects it to the signifier: 'the notion of structure is by itself already a manifestation of the signifier [...] when we analyze a structure it's always at least ideally a question of the signifier' (Lacan, 1993, pp. 183-4). When Lacan (1988[1931]) wrote about structure in the 1930s this was not yet linked to structuralist thinking or to the role of language in mental life. Indeed, in Seminar $I I I$, when analyzing elementary phenomena, Lacan thinks of these as manifestations at the level of the chain of signifiers, which is also true for neurotic symptoms. The underlying idea is that the mental continuity that we normally experience is determined by the sets of signifiers we use. Our private mental world, which consists of webs of ideas or signifieds, is coherent because we classify and name things and events that might possibly occur by means of signifiers. These enable us to experience regularities.

What is also characteristic of the signifying chain is that it enables anticipation and retroaction (see Lacan, 1957, 1960). Anticipation means that starting from one signifier I expect the occurrence of others. Indeed, as we speak, a set of expectations with respect to different probabilities is triggered, which installs the dimension of future experience: through anticipation, a number of expected signifying articulations are created mentally. Retroaction, in its turn, means that as the signifiers unfold, they affect the meaning associated with previously articulated 
elements of the signifying chain. Established ideas that were constituted via a previous set of signifiers might be underscored, challenged, or grow to be more complex when new signifiers are added to the earlier set.

Importantly, Lacanian theory not only attributes a meaning-generating function to anticipation and retroaction. Signifying articulation also generates the dimension of the subject (Fink, 1995; Vanheule, 2011). Via speech I present myself for myself and in relation to others. Speech entails an enunciating position through the articulation of signifiers. However, and crucially, this enunciating position is never fully or adequately represented by any of the signifiers I use (Feyaerts \& Vanheule, 2015). On the one hand, articulations of the signifying chain produce an enunciated subject: through retroaction I establish ideas concerning my identity in relation to the identity of others. Yet, these ideas never make up a whole and can contain contradiction, which is one reason why the subject is conceptualized as divided in Lacanian theory. On the other hand, our use of speech entails an enunciating subject. This means that all effort towards representation inherently blunders. In speech, while I might seem to cohere with what I have said, this is never the case: the saying never coheres with the said, which implies that the enunciating act as such actualizes the non-enunciated side of the subject. Therefore, the subject is not a fixed entity, but has an evanescent event-like character: in the tilting movement between signifiers the subject fades the moment it is named.

\section{Mental Automatism Considered Structurally}

In terms of these elements from Lacan's structural theory, mental automatism might be conceptualized as an unanticipated interference in the signifying chain. Whereas de Clérambault differentiates between different functional domains through which automatic phenomena are expressed (ideo-verbal, motor, sensory-affective), Lacan's focus is more abstract, concentrating on the logical organization of the interference that takes place. For example, in 'On a Question Prior to Any Possible Treatment of Psychosis,' when criticizing the psychiatric approach to hallucinations Lacan remarked the following:

Clinicians did better when they figured out that verbal motor hallucinations are often accompanied by the subject's own partial phonatory movements. Yet they did not articulate the crucial point, which is that, since the sensorium is indifferent in the production of a signifying chain:

(a) the signifying chain imposes itself, by itself, on the subject in its dimension as voice;

(b) it takes on, as such, a reality proportionate to the time, which is perfectly observable in experience, involved in its subjective attribution;

(c) and its own structure, qua signifier, is determinant in this attribution, which is distributive as a rule - that is, it has several voices and thus renders equivocal the supposedly unifying percipiens. (Lacan, 1959, p. 447) 
In his view the specific functional domain, or sensorial register (sensorium), affected in a hallucination is subordinate to the signifying process along which it is constituted: signifiers are imposed automatically onto the subject (component (a) from the quote); imposed signifiers disrupt the process of retroaction (and become more irrefutable the longer the initial bewilderment) (component (b)); and, as a result, the subject itself, which is an effect of the signifying articulation, is challenged and rendered ambiguous (component (c)).

While Lacan does not explicitly apply this line of structural reasoning to de Clérambault's mental automatism, both are compatible, as he suggests in 'On My Antecedents.'

Specifically, it might be argued that in positive automatic phenomena the course of anticipation and retroaction is disrupted because of the spontaneous occurrence of unanticipated parasitic signifiers that do not fit the line of signifiers along which the subject is constituted. These disrupt the coherence of the set of signifiers that one was actually using when making sense of the world. Given this missing coherence, no meaningful signifieds can be connected to such parasitic signifiers: retroactive movement fails to connect parasitic signifiers to other elements in the signifying chain, and therefore deeply disturb subjectivity. They confront the subject with a nonsensical element that cannot be attributed to an enunciating subject ('I'm not the originator of this thought/utterance/ action/feeling/perception'; 'it's not me, it happens in/to me'). This is exactly what gives them their peculiar epistemic status: because these parasitic signifiers cannot be attributed to an enunciating subject, they constitute an imposed body of knowledge, paranoid knowledge, which cannot be questioned. Unlike productions of the unconscious in neurosis, elementary phenomena are not experienced as expressions of one's own subjectivity. Productions of the unconscious in neurosis provoke surprise: displaced signifiers appear in unexpected contexts and, to paraphrase Freud (1919), provoke the feeling that one is not the master in one's own house. The emergence of positive elementary phenomena, by contrast, is accompanied by perplexity and dismay. They are manifestations of unthinkable or unimaginable signifiers, with which one, at least initially, feels no link. However, given that such invading signifiers interfere within the signifying chain that constitutes the subject, they cannot simply be put aside, and they affect the enunciated subject ('this thought/utterance/ action/feeling/perception concerns me'). By the imposition of a strange element in the midst of how the subject approaches the world, such parasitic signifiers undermine the identity he experiences both of himself and of others. To use Freud's metaphor, they destabilize the idea of having a safe haven that protects against the world outside. Elementary phenomena are bombs that (threaten to) make the house explode.

Paranoid knowledge cannot simply be integrated in the retroactive (meaning-generating) movement of the signifying chain, which not so much effaces the subject, but fundamentally questions whether it is still the subject 
who is speaking, challenging whether one is a subject at all, or an object subjected to external intentions. Indeed, when confusion at that point is replaced by a verdict, delusional activity starts: changes at the level of the enunciated subject are not attributed to an enunciating subject, but to an uncontrollable other one is merely subjected to. As already indicated, in Lacan's view delusions reiterate the pivotal point of interruption that also comes to the fore in elementary phenomena. Therefore, they should not be seen as interpretations, but as variations on the same structural point; that is, the point of rupture in the intimacy of life.

Negative automatic phenomena, in their turn, can be conceptualized as a radical rupture in the continuous unfolding of the chain of signifiers. Signifying articulation itself gets inhibited and blocked, and, as a result, anticipation in particular is undermined. What is lost in negative automatic phenomena is the materiality of the signifier itself. At the place where a signifier is expected to occur, given the trajectory of the signifying chain, desolate emptiness awaits, which, moreover, does not refer to anything ('my thought/utterance/ action/feeling/perception is disappearing'). The basic element upon which expectation builds is absent, and thus the end point of the utterance brings nothing but perplexity. Given this desolate emptiness, the meaning attributed to past and future events fails to be constituted. In this case, retroaction fails radically. To further rephrase Freud: in the case of negative elementary phenomena the house does not explode; it implodes. Indeed, the elementary absence of signifiers implies the disappearance of an enunciating subject and radically deters the creation of an enunciated subject. In this case, the divided subject simply fails to constitute itself. What remains is numb hollowness, and the loss of the ability to experience oneself as a continuity in space and time: the dimension of the divided subject, which appears as an undercurrent of signifying articulation, is annulled.

In terms of Lacan's structural theory from the 1950s, mental automatism concerns a functional-formal disruption that creates ambiguity and discontinuity in the signifying chain, which destabilizes the experience of the subject. It implies an estrangement in the process of thinking and feeling. The no doubt illusory, but constitutive, feeling of being the agent and owner of mental processes and of bodily experiences is lost.

Thus considered we can indeed conclude that, while in contrast with de Clérambault, Lacan does not discuss mental automatism in terms of specific functional domains, the process of disruption that de Clérambault describes is compatible with Lacan's structural approach from the 1950s, where elementary phenomena are events in the signifying chain that destabilize the subject. In terms of Lacan's distinction between the registers of the Real, the Symbolic, and the Imaginary, these are disruptions of the Real at the level of the Symbolic order. Order is lost, Symbolic disorder comes to the fore, and this threatens the subject since the material basis through which the subject is articulated (i.e. the chain of signifiers) is undermined. 


\section{From Causation to Determination}

Notwithstanding their structural compatibility, de Clérambault and Lacan frame mental automatism in rather different ways. Already in his doctoral thesis Lacan disagreed with de Clérambault's idea that elementary phenomena have an organic origin only, instead suggesting that they are evoked in relation to the other (Lacan, 1975[1932], pp. 211-17). For example, in his case study of Aimée he pointed out that 'vital situations' and 'moral conflicts' concerning her position towards her child, her sister, and her husband had a disturbing effect and triggered disturbances of the mental automatism type (Lacan, 1975[1932], p. 261).

In Seminar III Lacan further elaborated this idea, suggesting that 'the fertile moment' of triggering a psychotic episode comprises 'an emotional element in the subject's life, a crisis that in fact does involve his external relationships' (Lacan, 1993, pp. 17-18). However, what is crucial to Lacan's line of reasoning is that he relates the triggering of mental automatism to the confrontation with a radical failure or foreclosure in representing oneself via the signifier in relation to questions occurring at the level of the unconscious.

In this context, the subject is confronted with questions related to existence at the level of the unconscious. In line with the Nietzschean dictum that man is a sick animal, Lacan assumed that human functioning was only partly determined by biology or by environmental factors. His work on the mirror stage and the double mirror model made this clear (Lacan, 1949, 1961): natural maturation and instinctual patterns do not completely govern who we are, thus leaving us, at the level of being, with an unpleasurable need, called the lack-of-being or want-to-be (manque-à-être). Such 'organic discord,' wrote Lacan (1959, p. 461), necessitates a 'symbiosis with the Symbolic.' Indeed, in dealing with the Unbehagen, at the level of being, we use signifiers, and can live in terms of what culture and social contexts define as good ways of living. Thanks to our so-called symbiosis with the Symbolic, the precarious lack-of-being is turned into an articulated question of existence. Henceforth self-directed epistemic questions ('who am I?') and questions concerning the intentionality of the other ('what do you want?') make up the unconscious.

More specifically, in his 1959 paper on psychosis, Lacan pointed out that the unconscious is organized around a set of existence-related questions or dilemmas, which no signifiers can settle once and for all. These concern one's position with respect to parenthood and authority; life in the light of death; sexuality in relation to love and procreation; and sexuation, that is: the question as to whether, or how, one is a man or a woman (Lacan, 1959, pp. 461, 464). Daily life confronts us with these issues, and while no signifier can conclusively determine our identity, the stories we tell and the thoughts we have bear witness to the human attempt to resolve the vacillating position we occupy at the level of existence. What is more, this vacillation, as brought to the fore in our use of the signifier vis-à-vis questions related to existence, determines the subject. 
In 'On a Question Prior to Any Possible Treatment of Psychosis' Lacan (1959) differentiated psychosis and neurosis as two modes of dealing with questions of existence, which have direct implications for how the occurrence of elementary phenomena are determined. He argued that in neurosis the question pertaining to the intentionality of the other is addressed in terms of a lawful principle, which is presumed at the basis of the other's actions. In this clinical structure the subject takes shape through the belief that the other's actions are not random, but guided by meaningful principles: social and cultural laws determine what the other does, or should do. Lacan (1959) called this lawful principle the 'Name-of-the-Father.' What is more, by means of subsequent identifications that further attune the subject to the other's desire, self-directed epistemic questions ('who am I?') also obtain an answer. In psychosis, by contrast, the Name-of-the-Father is radically missing or foreclosed. No answer is created either for questions concerning the intentionality of the other or for self-directed epistemic questions, and as a result the experience of the subject is unstable.

What then determines the occurrence of elementary phenomena? They emerge in relation to the other when specific life-events provoke questions related to existence, but no support can be found in a Name-of-the-Father. In other words, the appeal to position oneself is made qua event, but no support is found in any signifier at all, and this produces an interruption in the signifying chain. At that point two possibilities come to the fore. Either one ends up in confusion, as the breach in the signifying chain is presented in all its rudeness. In that case the signifying chain dies out, resulting in negative mental automatism. The other possibility is that instead of dying out the signifying chain starts to function in uncontrolled ways, and alternative signifiers are produced in the reality of the subject, which results in positive mental automatism.

Indeed the hypothesis underlying Lacan's model is that confrontations with the foreclosure of a Name-of-the-Father determine mental automatism. Clinically speaking this implies that upon detecting elementary phenomena in a patient's discourse, the psychoanalyst needs to construct, through case formulation, how mental automatism might be associated to specific events of failure - failure to represent oneself by means of the signifier in relation to the other.

An added value of the Lacanian account of mental automatism is that it enables us to grasp why phenomena of mental automatism touch on specific contents. Foreclosure implies that specific issues concerning sexuality, death, relationships, and human intentionality cannot be addressed in lawful terms, and as a result they are expressed in a Real way through automatic phenomena, which manifest in wild, unexpected, and brutal ways, and confront the subject with contents that cannot be assumed by means of a Name-of-the-Father. Hence, for example, Judge Schreber's daydream that it must be beautiful to be a woman making love, which is an automatically imposed thought he, at least at first, cannot make sense of. The thought occurs at the moment he is notified about his appointment as Senatspräsident. This constitutes an appeal to assert his masculinity, which collapses, and suddenly a feminizing thought overwhelms him. Another example 
can be found in the case of Aimée: she fails to occupy a mothering position in relation to her son, and suddenly it comes to her mind that people want to hurt her baby. Indeed, what Lacan leaves aside are de Clérambault's causal explanations, replacing these with a focus on unconscious determination.

\section{Conclusion}

Starting from a general introduction on Gaëtan Gatian de Clérambault, and in particular his concept of mental automatism, this article examined two ideas from Lacan's 'On My Antecedents.' First I explored the connection between Lacan's concept 'paranoiac knowledge' and de Clérambault's 'mental automatism' in order to clarify why Lacan initially neglected the obvious connection between these concepts in his early work. A loyalty to Henri Claude appears to have been the main factor here. Next I examined Lacan's suggestion that de Clérambault's concept of mental automatism closely matched with his own structural approach to psychoanalysis, something that Lacan himself never demonstrated. I argued that from a structural perspective mental automatism comes down to a rupture in the continuity of the signifying chain, which provokes the disappearance of the subject. Negative mental automatism coheres with the occurrence of a gap in the chain of signifiers, and positive mental automatism coheres with the occurrence of unanticipated signifiers. Furthermore, I pointed out that Lacan's theory implies the hypothesis that manifestations of mental automatism are determined by a so-called foreclosure of the Name-of-the-Father in psychosis, whereby questions related to existence cannot be addressed by means of the signifying chain. Mental automatism attests to this. What is interesting about the link with Lacan's theory of foreclosure is that it enables us to explain why specific contents come to the fore in mental automatism.

Interestingly, the focus of this paper has implications for contemporary theory in the field of Lacanian psychoanalysis. In recent years Lacanian psychoanalysts developed a strong interest in 'ordinary psychosis' or 'cold psychosis': modes of subjective functioning that are not characterized by obvious hallucinations or delusions, but that nonetheless bear witness to psychosis (Miller, 2009; Leader, 2011; Redmond, 2014). In reference to Lacan's (1959) text 'On a Question Prior to Any Possible Treatment of Psychosis,' Miller suggests that above all ordinary psychosis is characterized by a disturbed self-experience consisting of the feeling that something is fundamentally wrong in life; an experience of 'a disturbance that occurs at the inmost juncture of the subject's sense of life' (Miller, 2009, p. 154). This disturbance is typically expressed in a feeling of externality or disconnection that manifests 'in the way you feel the surrounding world, in the way you feel your own body, and in the way you relate to you own ideas' (Miller, 2009, p. 154). Specifically, Miller (in IRMA, 1999, p. 290) suggests that such feeling of externality or disconnection might best be framed in terms of mental automatism. However, he does not elaborate how de Clérambault's concept fits with the Lacanian framework. The same is true for other authors working on this topic 
(Leader, 2011; Redmond, 2014). Hence the usefulness of establishing parallels and divergences between de Clérambault's mental automatism and Lacan's structural concept of psychosis.

Finally, this paper leaves several questions unaddressed. One point that deserves further study is how Lacan uses the concept of automatism in his discussion of Freud's Beyond the Pleasure Principle, as well as Aristotle's concepts tuché and automaton (Lacan, 1964; Verhaeghe, 2002). Both discussions are relevant in terms of de Clérambault's theory of mental automatism (Tevissen, 2008). Moreover, exactly how Lacan's weekly clinical case presentations, which he framed as actual analytic work (Miller, 1978), imply a turn away from de Clérambault's expertise-driven interviewing style should also be addressed (Haustgen \& Gumpper, 2012).

\section{References}

Ball, B. (1880) Leçons sur les maladies mentales. Paris: Asselin.

Biéder, J. \& Bénézech, M. (2016) Concerning the mental report of Maurice Utrillo by the alienist Gaétan Gatian de Clérambault. Annales médico-psychologiques 174: 226-30.

Claude, H. (1930) Mécanisme des hallucinations: Syndrome d'action extérieure. L'Encéphale 25: 345-59.

Dalí, S. (1930a) The rotting donkey. In S. Dalí, The Collected Writings of Salvador Dalí. Ed. H. Finkelstein. Cambridge \& New York: Cambridge University Press, 1998, pp. 223-6.

Dalí, S. (1930b) The sanitary goat. In S. Dalí, The Collected Writings of Salvador Dali. Ed. H. Finkelstein. Cambridge \& New York: Cambridge University Press, 1998, pp. 226-31.

de Clérambault, G.G. (1909) Première conception d'un automatisme mental générateur de délire. In G.G. de Clérambault, Oeuvres psychiatriques. Paris: Frénésie éditions, 1987, pp. $455-6$.

de Clérambault, G.G. (1920a) Automatisme mental et scission du moi. In G.G. de Clérambault, Oeuvres psychiatriques. Paris: Frénésie éditions, 1987, pp. 457-67. de Clérambault, G.G. (1920b) La fin d'une voyante. In G.G. de Clérambault, Oeuvres Psychiatriques. Paris: Frénésie éditions, 1987, pp. 613-31.

de Clérambault, G.G. (1923) Les psychoses hallucinatoires chroniques. In G.G. de Clérambault, Oeuvres psychiatriques. Paris: Frénésie éditions, 1987, pp. 470-91. de Clérambault, G.G. (1924a) Définition de l'automatisme mental. In G.G. de Clérambault, Oeuvres psychiatriques. Paris: Frénésie éditions, 1987, pp. 492-4.

de Clérambault, G.G. (1924b) Les psychoses hallucinatoires chroniques. In G.G. de Clérambault, Oeuvres psychiatriques. Paris: Frénésie éditions, 1987, pp. 495-526.

de Clérambault, G.G. (1925) Psychoses à base d'automatisme - Premier article. In G.G. de Clérambault, Oeuvres psychiatriques. Paris: Frénésie éditions, 1987, pp. 528-44. de Clérambault, G.G. (1926) Psychoses à base d'automatisme - Second article. In G.G. de Clérambault, Oeuvres psychiatriques. Paris: Frénésie éditions, 1987, pp. 544-76. de Clérambault, G.G. (1927a) Du rôle de l'affectivité dans les psychoses hallucinatoires chroniques. In G.G. de Clérambault, Oeuvres psychiatriques. Paris: Frénésie éditions, 1987, pp. 580-7.

de Clérambault, G.G. (1927b) Discussion du rapport de M. Nayrac sur l'automatisme mental au congrès de Blois. In G.G. de Clérambault, Oeuvres psychiatriques. Paris: Frénésie éditions, 1987, pp. 587-99.

deClérambault, G.G. (1933) Syndrome mécanique. In G.G. de Clérambault, Oeuvres psychiatriques. Paris: Frénésie éditions, 1987, pp. 607-8.

Ey, H. (1952) Études psychiatriques: Tome I. Paris: Desclée de Brouwer. 
Feyaerts, J. \& Vanheule, S. (2015) How to return to subjectivity? Natorp, Husserl, and Lacan on the limits of reflection. Theory \& Psychology 25: 753-74.

Fink, B. (1995) The Lacanian Subject: Between Language and Jouissance. Princeton, NJ: Princeton University Press.

Freud, S. (1919) The 'Uncanny'. In S. Freud, The Standard Edition of the Complete Psychological Works of Sigmund Freud. Trans. from the German by J. Strachey. London: Hogarth Press, vol. 17, pp. 217-56.

Garrabé, J. (2005) Clérambault, Dali, Lacan and the paranoiac interpretation. Annales médico-psychologiques 163: 360-3.

Gumpper, S. \& Haustgen, T. (2012) Gaëtan Gatian de Clérambault (1872-1934) I. Sa vie et son oeuvre. Annales médico-psychologiques 170: 224-30.

Haustgen, T. \& Gumpper, S. (2012) Gaëtan Gatian de Clérambault (1872-1934) II. Son heritage psychiatrique. Annales médico-psychologiques 170: 358-63.

Hriso, P. (2002) Mental Automatisms: A Conceptual Journey into Psychosis: Commentaries and Translation of the Work of Gaëtan Gatian de Clérambault. Bayonne, NJ: Hermes Whispers Press.

IRMA (1999) La Convention d'Antibes: La psychose ordinaire. Paris: Agalma.

Lacan, J. (1933) Motifs de crime paranoïaque - le crime des sœurs Papin. Minotaure 3/4: $25-8$.

Lacan, J. (1935) Compte-rendu de 'Le temps vécu. Études phénoménologiques et psycho-pathologiques' de E. Minkowski. Recherches philosophiques 5: 424-31.

Lacan, J. (1947) Presentation on psychical causality. In J. Lacan, Écrits. Trans. B. Fink. New York \& London: W.W. Norton, 2006, pp. 123-58.

Lacan, J. (1949) The mirror stage as formative of the I function as revealed in psychoanalytic experience. In J. Lacan, Écrits. Trans.B. Fink. New York \& London: W.W. Norton, 2006, pp. 75-81.

Lacan, J. (1957) The instance of the letter in the unconscious, or reason since Freud. In J. Lacan, Écrits. Trans. B. Fink. New York \& London: W.W. Norton, 2006, pp. $412-42$.

Lacan, J. (1959) On a question prior to any possible treatment of psychosis. In J. Lacan, Écrits. Trans. B. Fink. New York \& London: W.W. Norton, 2006, pp. 445-88.

Lacan, J. (1960) The subversion of the subject and the dialectic of desire in the Freudian unconscious. In J. Lacan, Écrits. Trans. B. Fink. New York \& London: W.W. Norton, 2006, pp. 671-702.

Lacan, J. (1961) Remarks on Daniel Lagache's presentation: 'Psychoanalysis and Personality Structure'. In J. Lacan, Écrits. Trans. B. Fink. New York \& London: W.W. Norton, 2006, pp. 543-74.

Lacan, J. (1964) The Seminar, Book XI, The Four Fundamental Concepts of Psychoanalysis. New York \& London: Karnac.

Lacan, J. (1966) On my antecedents. In J. Lacan, Écrits. Trans. B. Fink. New York \& London: W.W. Norton, 2006, pp. 51-7.

Lacan, J. (1975[1932]) De la psychose paranoïaque dans ses rapports avec la personnalité. Paris: Seuil.

Lacan, J. (1988[1931]) Structure des psychoses paranoïaques. Ornicar? 44: 5-18.

Lacan, J. (1993) The Seminar of Jacques Lacan: Book III, The Psychoses, 1955-1956. Ed. J.-A. Miller. Trans. R. Grigg. New York \& London: W.W. Norton.

Lanteri-Laura, G. (2004) Principales Théories dans la psychiatrie contemporaine. Encyclopédie médico-chirurgicale 37-006-A-10.

Lanteri-Laura, G. \& Daumézon, G. (1961) La Signification sémiologique de l'automatisme mental de Clérambault. Recherches sur les maladies mentales 1: 61-91.

Leader, D. (2011) What is Madness? London: Penguin.

Leguil, F. (2002) Préface: Clérambault et les leçons de la passion. In G.G. de Clérambault: L'Érotomanie. Paris: les empêcheurs de penser en rond \& Seuil.

Lévy-Valensi, J., Migault, P. \& Lacan, J. (1931) Écrits 'inspirés': Schizographie. Annales médico-psychologiques 2: 508-22. 
Maleval, J.C. (2001) G.G. de Clérambault loin de l'oubli. L'Évolution psychiatrique 66: 223-39.

Michaux, L. (1973) G.-G. de Clérambault et l'Infirmerie Spéciale. Confrontations psychiatriques 11: 41-54.

Mignard, M. \& Petit, G. (1912) Délire et personnalité. Bulletin de la Société de Médecine Mentale de Belgique 160: 449-62.

Miller, J.-A. (1978) Enseignement de la presentation de malades? Ornicar? 10: 13-24.

Miller, J.-A. (2009) Ordinary psychosis revisited. Psychoanalytical Notebooks 19: 139-67. Milner, J.C. (2002) Le Périple structural: Figures et paradigme. Paris: Seuil.

Redmond, J. (2014) Ordinary Psychosis and the Body. London \& New York: Palgrave Macmillan.

Renard, E. (1992) Le Docteur Gaëtan Gatian de Clérambault: Sa vie et son oeuvre (1872-1934). Paris: Institut Synthélabo.

Roudinesco, E. (1993) Jacques Lacan. Paris: Fayard.

Roudinesco, E. (1994) Histoire de la psychanalyse en France. Paris: Fayard.

Rubens, A. (1998) Le Maître des insensés: Gaëtan Gatian de Clérambault (1872-1934). Paris: Institut Synthélabo.

Sauvagnat, F. (1999) Secrétaire de l'aliéné aujourd'hui. Ornicar? Digital 77: 1-13.

Tevissen, R. (2008) The indeterminism of mental automatism and its relation to chance and contingency throughout the history of psychiatry. PSN - Psychiatrie Sciences Humaines Neurosciences 6: 38-53.

Trichet, Y. (2011) L'Entrée dans la psychose: Approches psychopathologiques, cliniques et (auto-)traitements. Rennes: Presses Universitaires de Rennes.

Vanheule, S. (2011) The Subject of Psychosis: A Lacanian Perspective. London \& New York: Palgrave Macmillan.

Verhaeghe, P. (2002) Causality in science and psychoanalysis. In J. Glynos \& Y. Stavrakakis (eds), Lacan and Science. London \& New York: Karnac, pp. 119-45.

\begin{abstract}
In 1966, in a paper on those who have influenced his work, Jacques Lacan suggested that his concept of 'paranoid knowledge' and his structural approach to psychoanalysis were closely linked to the work of Gaëtan Gatian de Clérambault. This article examines both of these points. Starting with an introduction to de Clérambault, focusing on his concept 'mental automatism,' the link between 'mental automatism' and 'paranoid knowledge' is discussed. Loyalty to Henri Claude and conflicts around theoretical and clinical issues seem to lie at the basis of Lacan's initial neglect of his conceptual indebtedness to de Clérambault. Second, the author discusses the presumed connection between mental automatism and Lacan's structural psychoanalytic theory, which Lacan did not elaborate. It is argued that from a structural perspective, mental automatism comes down to a rupture in the continuity of the signifying chain, which provokes the disappearance of the subject. Furthermore, Lacan's theory implies the hypothesis that manifestations of mental automatism are determined by a foreclosure of the Name-of-the-Father, where questions related to existence cannot be addressed in a stable way. Lacanian theory thus retained de Clérambault's notion of a rupture in mental life that lies at the basis of psychosis, but replaced his biological framework with the dimension of the subject as produced through speech.
\end{abstract}

Key words: psychosis, psychoanalysis, paranoia, hallucinations, delusions, subject, Lacan, mental automatism, de Clérambault 


\section{Your short guide to the EUP Journals Blog http://euppublishingblog.com/}

A forum for discussions relating to Edinburgh University Press Journals

\section{The primary goal of the EUP Journals Blog}

To aid discovery of authors, articles, research, multimedia and reviews published in Journals, and as a consequence contribute to increasing traffic, usage and citations of journal content.

\section{Audience}

Blog posts are written for an educated, popular and academic audience within EUP Journals' publishing fields.

\section{Content criteria - your ideas for posts}

We prioritize posts that will feature highly in search rankings, that are shareable and that will drive readers to your article on the EUP site.

\section{Word count, style, and formatting}

- Flexible length, however typical posts range 70-600 words.

- Related images and media files are encouraged.

- No heavy restrictions to the style or format of the post, but it should best reflect the content and topic discussed.

\section{Linking policy}

- $\quad$ Links to external blogs and websites that are related to the author, subject matter and to EUP publishing fields are encouraged, e.g.to related blog posts

\section{Submit your post}

Submit to ruth.allison@eup.ed.ac.uk

If you'd like to be a regular contributor, then we can set you up as an author so you can create, edit, publish, and delete your own posts, as well as upload files and images.

\section{Republishing/repurposing}

Posts may be re-used and re-purposed on other websites and blogs, but a minimum 2 week waiting period is suggested, and an acknowledgement and link to the original post on the EUP blog is requested.

\section{Items to accompany post}

- A short biography (ideally 25 words or less, but up to 40 words)

- A photo/headshot image of the author(s) if possible.

- Any relevant, thematic images or accompanying media (podcasts, video, graphics and photographs), provided copyright and permission to republish has been obtained.

- Files should be high resolution and a maximum of $1 \mathrm{~GB}$

- Permitted file types: jpg, jpeg, png, gif, pdf, doc, ppt, odt, pptx, docx, pps, ppsx, xls, xlsx, key, mp3, m4a, wav, ogg, zip, ogv, mp4, m4v, mov, wmv, avi, mpg, 3gp, $3 g 2$. 